\title{
A Practical Note on Transferring Ideas and Methods from Consultancy Practice to the MPA Classroom A Personal Account from a Danish Case Study
}

\author{
Ry Nielsen, Jens Carl; Quinn, Brid
}

\author{
Document Version \\ Accepted author manuscript \\ Published in: \\ Teaching Public Administration \\ DOI: \\ $10.1177 / 0144739415615662$ \\ Publication date: \\ 2016 \\ License \\ Unspecified
}

Citation for published version (APA):

Ry Nielsen, J. C., \& Quinn, B. (2016). A Practical Note on Transferring Ideas and Methods from Consultancy Practice to the MPA Classroom: A Personal Account from a Danish Case Study. Teaching Public Administration, 34(1), 83-95. https://doi.org/10.1177/0144739415615662

Link to publication in CBS Research Portal

\section{General rights}

Copyright and moral rights for the publications made accessible in the public portal are retained by the authors and/or other copyright owners and it is a condition of accessing publications that users recognise and abide by the legal requirements associated with these rights.

\section{Take down policy}

If you believe that this document breaches copyright please contact us (research.lib@cbs.dk) providing details, and we will remove access to the work immediately and investigate your claim. 


\section{A Practical Note on Transferring Ideas and Methods from Consultancy Practice to the MPA Classroom: A Personal Account from a Danish Case Study}

\section{Jens Carl Ry Nielsen and Brid Quinn}

Journal article (Post print version)

This article was originally published in Teaching Public Administration. First published online 01 December 2015.

๑Ol: 10.1177/0144739415615662

Uploaded to Research@CBS: February २०16 


\title{
A Practical Note on Transferring Ideas and Methods from Consultancy practice to the MPA clasroom: a personal account from a Danish Case Study
}

\author{
J.C. Ry Nielsen, Copenhagen Business School and Brid Quinn, University of Limerick
}

Ideas come while you work, not while you wait for them ${ }^{i}$

\begin{abstract}
At the lead author's home institution - Copenhagen Business School (CBS) - the combination of theory and practice is seen as very important in teaching. Research-based teaching is the slogan. In this respect $C B S$ has the same ambition as other universities. But it seems as if CBS has an advantage at the master's level, because students come with a lot of experience. The average age of the MPA students is generally over 40. Consequently, they are able to bring practice into the classroom and to confront it with theories and also the experiences of their fellow students. There are, however other ways of bringing practice and theory together. In this note the author reviews a 3 year consultancy/research project in a merging hospital department. The aim of the note is twofold. One is to detail the more exploratory methods used to develop the organization. The second is to evaluate whether these methods can be transferred to a potential MPA module at CBS. It is concluded that for some of the methods suchas diary keeping and agenda setting, transfer is easy. Other methods such as using a cross sectional group or manager role-analysis may not transfer easily but could be applied in the home organizations of participants. The design of the module and the non-traditional roles of the teachers are very important for successful implementation.
\end{abstract}

Keywords research teaching Copenhagen Business School explorative methods master programme transfer implementation

\section{Part 1: Introduction}

At the author's home institution, Copenhagen Business School (CBS), the combination of theory and practice in teaching is given high priority. As in other higher education institutions researchbased teaching is almost a mantra (www.cbs.dk). Combining theory and practice is easier at the 
masters' level because participants come with a lot of experience that can be utilized in class and in assignments. For the MPA programme at CBS we created a motto that expresses the importance of the theory-practice linkage. Our motto 'from nearness to distance - and back again' recognises that

participants come with a lot of knowledge, problems and solutions from their daily life- the nearness dimension. The teachers and fellow participants provide the helicopter perspective with theories, cases, discussions, and assignments - the distance and objectivity dimensions. For CBS graduates the MBA is not just an academic exercise. It enables participants to return to their organisations and become change agents using the academic and experiential insights developed during the MPA programme (see www.mpa.dk). The MPA approach used in CBS can thus be seen to reflect the literature that deals with transfer from the classroom to the real world, see, for example., Keller et al (2011). This reflective article has a different point of departure. It investigates the possibility of transferring ideas and methods from an action research/consultancy project in a hospital department into a module for the Master of Public Administration (MPA) programme at CBS. The article describes a learning experience in the real world, i.e., a hospital setting, and looks at transferring ideas from there to the classroom.

\section{Clarification of content}

The article has deliberately been labelled 'A Practical Note'. 'Practical' because the article is very specific and does not focus much on theory, in contrast with, for example, the articles by Quinn and Oldfield in this volume. It has a narrow focus on the pedagogical content of the specific case which means that other perspectives such as process consultation, merger theory or teambuilding are not dealt with By using the word "note" the intention has been to emphasise the academic non- pretentious character of the contribution. Rather, the ambition has been to demonstrate in detail what can be drawn from pedagogical analysis of a real-life issue in order to design a potential MPA module. Written by the consultant it is an insider perspective with much of the data coming from memory and notes. Part two outlines the specific context of the case. It first provides a description of the case organization - a hospital department which is a merger of three previously independent departments. Then the author's relationship with the case organization and the points of departure are outlined. The section ends with a short description of the overall MPA programme and the specific module design based on the hospital case. In part three the methods applied in the change project are detailed and the transfer possibilities discussed before the ideas that can be applied in class are outlined. Part four reflects on the process and content of the case abefore conclusions are drawn in part five draws conclusions 


\section{Part 2 Contexts}

The case organization and the merger

The case organization, which shall be referred to as the G-case, is the Diagnostic Department of a large hospital in the Capital Region of Denmark The hospital has 2.500 employees, 350 beds and 250.000 outpatient treatments per year.The Diagnostic Department (DD) has 215 employees and 200.000 patient contacts per year. The DD is the result of a merger inDecember 2012. The merger process consisted of bringing three previously independent departments together in one organization, the DD The three departments were Radiology (90 employees), Clinical Physiology and Nuclear Medicine (40), and Clinical Biochemistry (60). Finally there is a medical research group of 25 employees.

Mergers are often used as money saving instruments but not in this case. The top management group of the hospital declared at the outset that the main purpose of the merger was to make patient-care more effective. The motivation was thus a professional one.

This clarification removed a lot of anxiety in the organization, thereby creating better conditions for the merger processes and establishing cross sectional collaboration. The new organization was rather unique in a Danish hospital context and the management structure of the DD was different, too. The designated management group of the new entity consisted of three people: the chief physician, the chief radiographer and the chief technologist. They were supported by three chief physicians from the three new sections. Before long it was decided that the management group should consist of all six, and they lightheartedly named themselves 'the Sixpack The group quickly realized that they had no experience of mergers and agreed to seek outside help. Consequently, the chief physician ( a graduate of the MPA programme directed by the author) arranged for the author to act as consultant for the merger process. The group took the task of leading and managing the organization very seriously and committed to bi-weekly 'consultant meetings' to discuss organisational developments.. In total 42 two-hour meetings were held. From the very beginning, the group decided to go public with the merger processes and outcomes. They sought to identify what went well, what went wrong, what was learnt and what others could learn. Therefore, they also hired a young sociologist, (Line Nicolaisen) who in collaboration with Sixpack and the author produced a report on the merger processes and life in the organization over the last three years (Nicolaisen 2015)

The Sixpack were confident about selecting the author as external consultant for the merger process because of his skill as a process-oriented teacher (as observed by the chief physician), his consultancy experience and his reputation as an author on organizational change. The author came to the process with an open mind in the Engelundian mode, ready to work with organization as it evolved and to work with the ideas that emerged from the merger process. This openness was coupled with a very broad repertoire of different theories and practical experience that could be applied during the unprecedented merger process 


\section{Imagining and designing an MPA module}

As the merger progressed it became clear that ideas and methods emerging from the process could be incorporated into the MPA model. This section outlines how this could be realized through development of an innovative module to be included in the MPA programme at CBS (www.mpa.dk). The MPA programme at CBS is more than 20 years old and is a two year midcareer part-time programme. Students come primarily from the public sector, but also from voluntary organizations eg., trade unions. Students have very broad experience as the average age of the students is more than 40 years. Both genders are equally represented. One of the hallmarks of the existing programme is the emphasis on establishing a cohesive cohort with each iteration of the programme. This is considered very important ${ }^{\mathrm{iii}}$ and creates psychological safety for participants. So it is customary to hold a two-day introductory workshop off-campus at the beginning of each MPA programme .

\section{The Merger module}

The new module will be labelled Leadership and organizational change; from practice to theory. The module will be an elective, placed in the thirs semester of the programme. The design of the new module borrows heavily from the existing module on Leadership practice and theory but incorporates the insights from working on the G_case

The new module will consist of 8 weekly lessons of 4 hours' duration, some of them conducted in one of the participants' organization. Participants will also be shadowed for one day by a fellow student. The pedagogical approach will be workshop-like, i.e. that there will a highdegree of participation. Students will make presentations on module readings and their application to students' home organization $^{\text {iv }}$ As is the norm for MPA programme at CBS the module literature will familiarise students with different theoretical perspectives There will always be two teachers in class as co-teaching works very effectively in mid-career teaching. MPA participants already collaborate in "permanent" work groups with 4 members which usually generate $s$ a high degree of psychological safety. These work groups will be an integral part of the new module Assessment will take the form of a small written synopsis that the group or the individual student will then discuss with two assessors. It is envisaged that the module would work effectively for classes of up to 24 students.

\section{Part 3: The process, ideas, methods, and transfer possibilities}

The merger experience drew on old and new learning activities. Some tried and tested methods such as ' shadowing' and picture metaphors were gainfully employed as illustrated by the Sixpack's depiction of collaboration below (Nicolaisen, 2015:1) 


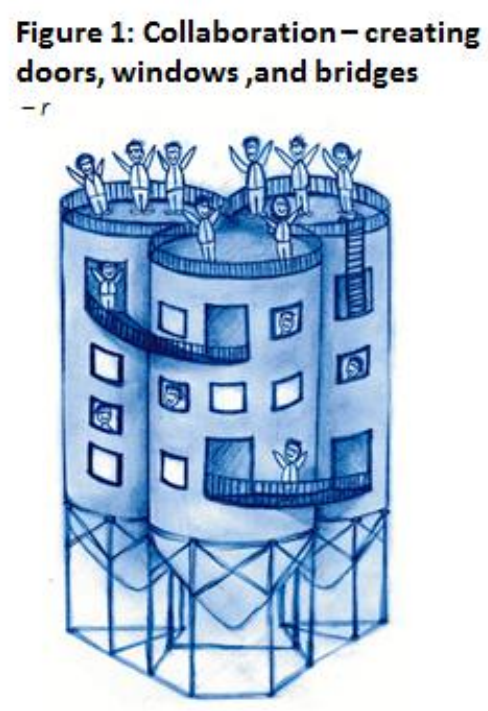

Other standard pedagogic techniques were used in the non-pedagogic setting . A lot of literature on leadership and organizational change was distributed to the Sixpack, although only a few articles were directly discussed. Members of the Slxpack had a natural science perspective and articles such as that on the garbage can model (March and Olsen 1995) were used to show a different, interesting and new way of analyzing life in the organization. Another strategy was to expose them to the latest research. One such example was the new PhD dissertation written by Per Østergaard from the University of Aalborg and reported in DJØF- bladet (January 2014) which found that many top managers start their management career as children, either as scouts or in sport, something that was true of many of the Sixpack.

Discussing situations that individual members found bizarre and difficult to handle was another useful strategy. This enabled them to identify the real issues, learn more about their personal styles of management and increase their repertoire for handling problem situations. Facilitating input from members who were participating in Continuous Professional Development and/or management education programmes enriched the process and provided insights that might have otherwise remained untapped. Assumptions and stereotypes were challenged in a fun way by party activities such as matching childhood photographs and personal music selections to group members. This led to revelations about hobbies, personal interests etc. which increased group cohesion.

Many of the above strategies are variations on adult-learning techniques but the remainder of this section will focus on processes, ideas and methods used in the merger project which have not been previously employed in the MPA classroom. It is in this section that the possibilities of transfer and application are explored. Most of the ideas for classroom innovation emerged from work with the Sixpack but ideas also emerged from a cross sectional group which was established in the spring of 2013. 
Since the bi-weekly meetings were the key element of the consultancy process, consultancy efforts sought to maximize their effectiveness. The model for learning and development previously elaborated in the author's MPA classes formed a useful basis for guidance of the merger process. The model is depicted in Figure 2 (based on Ry Nielsen, 2013:59). Recently, Nicolaisen used the model as the structure for the report on the merger process (Nicolaisen, 2015).

Figure 2:

A MODEL FOR DEVELOPMENT AND LEARNING

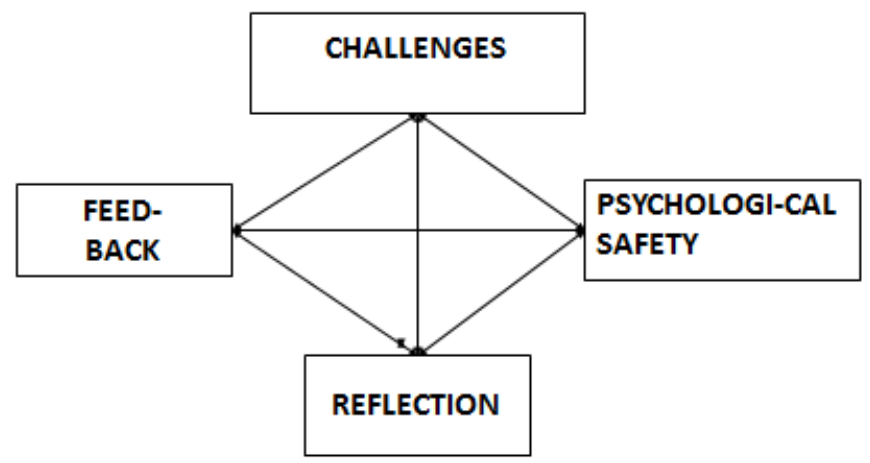

RY/IOA/MPQ/CBS

From the start of the consultancy, creating psychological safety for those involved was key, although the development and learning model was not introduced immediately. Throughout the entire process, the importance of the psychological safety dimension in handling challenge and change was emphasised and was evident in situations such as getting and giving feedback and reflecting on actions and developments.

Another useful strategy was application of the Senge (1990) distinction between dialogue and discussion. In a dialogue one listens and argues in order to become more clever, getting more insight. In a discussion you argue to win and thus often create conflict. Previous experience with management groups found that they thought the distinction very interesting and fruitful, but difficult to apply. Over time it was possible to note a shift from discussion to dialogue within the Sixpack.

Although the diary as a learning method has a long history dating back to Carlson (1951), the way in which journaling was used in this project was innovative.Believing that transparency in the group members' work could be an important step in the development of the group, the author saw the application of the logbook/diary method ${ }^{v}$ as a vehicle to achieve this. More specifically the idea was that Sixpack should keep a diary for two weeks and then report back to the group on what they had learned during the process and afterwards. Later on we labelled this process " from 
personalization to collectivization", a variation on the term coined by a colleague, Søren Christensen.

To support the diary-keeping and reflective processes the group was given articles on managing in many directions: upwards, downwards, laterally, outwards, etc (e.g., Nielsen,1997;

Mintzberg,1973).

The first attempt at keeping a diary proved to be rather difficult, because discussion had not taken place on precisely what the content should be. Nevertheless recording their daily activity was an eye - opener for the participants who found themselves asking "Is this really what I do?" The dialogue in the group afterwards turned out to be very fruitful, as it made the group members' work more transparent for each other, promoting questions and answers that would otherwise not have been on the table. It also promoted what one could call more holistic standpoints on the organization. The whole exercise thus became the first of many examples of the above-mentioned personalisation to collectivization process. A second logbook exercise was undertaken in January 2013. Using the learning from the first round, treatment of the logbook was more precise. On a daily basis, positive and negative events were recorded, and at the end of each week managers were required write a structured reflection The reflection was expected tocontain action (what did I do), cognitive elements (what did I think) and affective elements (what did I feel) $^{\mathrm{vi}}$ The follow up was also different this time. Each member of the group selected two topics for a conversation with the consultant. The conversation was recorded, and afterwards the participant wrote up the minutes of the conversation followed by a written reflection on process and outcome. Each reflection on outcome was circulated to all members of Sixpack and put on the agenda for a Sixpack meeting.

In the group dialogue afterwards it was obvious that the members had become more conscious about their managerial and leadership roles. They also recognized the importance of balancing individual and collective elements. In Klausen's terms (2001:240) they had to be loyal both to the small (the section) and the big community (DD). From the reflective journalling process, managers could see themselves as role models for collaboration across sections in the department. Gradually, the journalling process prompted individual managers to share their ideas, problems and experiences with the group in a structured and purposeful way and they agreed that it had been an excellent practical and reflective exercise.

\section{Transfer to and application in the class room?}

This section focuses on the kernel of the issue: How to implement the hospital experience in an MPA class room. Because the psychological safety dimension has been established in the MPA programme's introductory workshop it can be assumed that the dialogue will be open and frank. The simple logbook exercise would seem rather easy to transfer to the classroom because it is easy to explain and will benefit from using the permanent groups as the knowledge-sharing unit. Learning from the G-case experience, however, it would be necessary to clarify the purpose, 
content and treatment of the journal data in the group if the method is to be successful. The more complex logbook exercise would also be interesting to use, but is time consuming as a classroom exercise. As with other elements, having trialled the process in the classroom,participants could apply the idea in their home organization, achieving a practice-theory-practice approach.

\section{Agenda setting}

The bi-weekly meeting process proved fertile ground for ideas which could transfer to the midcareer classroom After a few meetings of the Sixpack it was agreed to set up an agenda with the same topics as the beginning of all meetings, namely: what has happened since last time ? What will happen tomorrow? Surprisingly, these two simple topics served to facilitate to a very high degree of both discussion and dialogue. They helped create transparency about life in the silos and more generally about the hospital setting. They also helped the individual managers to set the scene for group discussions on specific issues e.g., one manager's personnel problems. The group usually posed good questions and sometimes framed good answers. Finally, the recurring agenda items also helped to balance the merger activities with 'ordinary life' in the sections by fostering dialogue on the small and big community. Thus careful agenda-setting contributed to improved problem solving capacity. As a consequence the DD perspective became more commonplace in group interactions. However, as the Sixpack later pointed out, the positive effects were highest in the second year of the merger. Later on they decided that the two topics took up too much time with too little outcome so a looser agenda was agreed.

\section{Transfer?}

This structured dialogic method developed in a real setting would seem to be easy to apply in classrooms with small groups of participants. In each lesson the teachers could allocate time to the group , to shareand reflect on what had happened since theprevious session. The group would have to decide on the structure of the session and also how they would evaluate both the process and outcomes. The positive effects should be the same for student groups as for the Sixpack and maybe even provide more added value because MPA participants do not have hierarchical relationships, making it easier to be honest and frank.

\section{More than the Sixpack}

\section{The cross sectional group}

Although merger activities were discussed in many fora in the hospital, it became clear that a forum where the merger was not the main topic would be beneficial. The Sixpack could immediately see the potential of input from a group like this and therefore agreed to the establishment of the group. Some of Sixpack would also participate in the first meeting, answering possible questions from the new group. The new group thus served as a vehicle for keeping the balance between merger-related issues and ordinary life in the sections/silos. The group was formed of members from the three sections. Its first meeting was on April $10^{\text {th }} 2013$ and the group 
selected that date as the group title. The consultant had previously used this approach with an international company. Since April 2013 the group has met twice a year. The membership rotates with 2-4 new members in each meeting. Over time it has been decided that only non managerial members of DD can be participants.

The content of meetings has been twofold. One aspect is 'life in the organization'. Under this heading the group has, for instance, compared the DD as workplace with the group's notion of an excellent workplace. Secondly, the group has decided on some of the content of the project days for all staff. The group has shown a high degree of openness and has been very constructive in the debates. This may be based on the fact that they consider the DD a fine workplace. The meetings have been facilitated by the consultnat and Line Nicolaisen.

\section{The middle managers}

It is easy to recognize that the role of the middle managers would change not only due to the merger but also due to the ongoing implementation processes. First, instead of having their own full time department head, they now had to compete with the Sixpack for attention. They often saw themselves as losers in this battle - just as many of the private members did. Second, they were expected/forced to act more independently both in managing the system and leading people. Many of them found this very difficult and needed help, which was not always available. The Sixpack often discussed the competencies lacking in the middle managers.

After some positive personnel changes in the group of middle managers, the Sixpack decided to focus on the group by organizing three seminars for them which were facilitated by the consultant and the process observer. Two were for the group alone while the last seminar also included the Slxpack. The seminar content was about life in the organization, roles, meeting structure and conducting difficult interviews. The seminars provided a forum to discuss the future of the organisation since the Capital Region had just announced a merger of the G-hospital with the much larger and very much prestigious National Hospital.

As with the cross sectional group the debate during seminars was open, constructive, and frank. The group agreed that DD was a fine workplace and that they enjoyed working there. As in other contexts, a shared identity emerged and the relationship between the Sixpack and the group deepened. Finally, the group was confident that they could cope with the merger although anxiety continued with regard to the future.

\section{Transfer}

Both the cross sectional group and the role of the middle managers are topics that can be touched in the permanent group, but they more belong to discussions in the home organizations of the participants

\section{Involvement}

One recurrent item in the Sixpack meetings was the involvement dimension. The problem of how to make as many employees as possible active and involved is a frequent dilemma in organizational change. The Scandinavian participation approach to organizational change (see, for 
example, Gustavsen, 1991), which sees democratic dialogue as essential in change processes was a strong source of inspiration for ways to increase participation during the merger. Many strategies and arenas to increase involvement were generated, models which can easily serve as classroom examples. The involvement strategies used included : 10 cross sectional project groups which yielded a 10\% improvement in patient care (Nicolaisen:2015); meetings for all staff, in the sections, in the joint committee and with top management ; interactive project days for all staff; a newsletter and an annual report. These activities increased involvement and 'buy-in' and their success in the hospital context provides a practice example which lends itself to theoretical analysis in the classroom. Other practice-based insights which lend themselves to theoretical analysis also emerged from the merger. As a result of the processes, the Sixpack developed a Lindblomian realisation that change had to be incremental and not radical, but still with a purpose (Quinn,1992). The minutes from meetings provide evidence for classroom analysis of the how this understanding developed over time. Similarly, there was a gradual acceptance that change processes demand time and patience and cannot be rushed. Thus, the G-case can provide valuable practice-based material for classroom discussions on organizational change.

\section{Part 4: Results and Reflections: Transfer in practice; the roles of Sixpack and the consultant}

It would appear that many of the different ideas and methods can be transferred to the MPA class or the home organization of MPA participants. But in designing the new module it is important to look at the different methods/dimensions/mechanisms from a practical transfer and implementation point of view. The module design will obviously facilitate the transfer, as will the following programme elements: the experienced participants; the two teacher system; the positioning of the module in the second year of the programme; the small size of the cohort ; the use of permanent groups and the fact that some of the teaching will take place in participants' organisations. However, successful transfer will require teachers to select the appropriate topics and methods and produce module descriptions likely to appeal to prospective participants. To ensure effective transfer, teachers who have atypical competences and a broad repertoire of theories and experiences must be selected since their primary role in the module will be as facilitators both in the group processes and in the transfer of ideas from the small groups to the whole cohort, so that knowledge sharing can take place in line with the model for learning and development depicted in figure 2.

The role of Sixpack

It is obvious that implementation of the different methods was only possible, because the Sixpack actively supported experimentation. The group was eager to learn and had a very open and positive attitude towards new initiatives. In this context the biweekly meetings played a significant role in the development of the group and establishing a good team dynamic In an evaluation in February this year they all pointed out that they now saw themselves as having 
espoused a holistic view of the organization and being pro-active in solving problems across the organization. Summing up one could say that the implementation of the merger also created the opportunity for leadership and management development for the Sixpack. So it was gratifying when the group won the Capital Region's Leadership Prize in 2013!

\section{The benefits of using an external consultant}

Reflecting on the project it is clear that having an external facilitator helped the group

- to become much better at collectivization;

- to recognise the need for balancing the demands from both the small and the big communities

- to engage in fruitful dialogue

- to treat the participation dimension very seriously, -

- to learn to live with uncertainty - and although the answer might still be blowing in the wind, answers do exist!

The openness in the organization not only enabled the merger process and Nicolaisen's constructive evaluation but also facilitated development of this pedagogical perspective, generating new tools and methods and expanding the teaching repertoire for mid-career classrooms.

\section{Part 5: Closing the chapter}

Writing and rewriting this note has been a fascinating journey depicting three years of learning with and through the DD. The decision to describe the experience from a pedagogical perspective, forced the author to look at the methods and ideas with new eyes. Help was forthcoming from many sources (see acknowledgements). It is hoped that the reader will find inspiration in the pedagogical tools and will try to implement them - and have great fun in doing so.

\section{Epilogue}

On February $13^{\text {th }}$ this year the board of directors at The National Hospital decided that the DA should go back to the original structure with three different sections that should then merge with the corresponding sections at The National Hospital.

Sixpack were very much disappointed over both result and process. They thought they had not been been taken seriously and they found it very sad that the board was not interested in an experiment as the continuation of DD would be.

Nonetheless Sixpack maintains that they will bring a lot of positive experience into the new organization and keep hold of the cross sectional results. 


\section{Acknowledgements}

Constructive comments were received from the Copenhagen Forum in Rotterdam, October 2014. The Sixpack provided positive feedback on the first draft. Line Ncolaisen was an excellent collaborator/sparring partner in the processes in the organization The editors of this special volume, Frans-Bauke van der Meer and Peter Marks believed in the project and provided many constructive suggestions and comments.

The outright comments of the peer reviewers resulted in much clarification and rewriting which enhanced the article.

But mostimportant was the help from Brid Quinn. She put so much effort into improving the text that the lead author suggested that she should be co-author, which she accepted.

\section{Notes}

1 Svend Engelund, Danish painter

2 See www.rh.dk

3. In all evaluations the MPA students agree that the cohesiveness is successfully achieved and also very important, see Pedersen and Ry Nielsen (2011)

4 See more on the student participation in the CBS programme in Ry Nielsen (2008)

5. The Feet( action) Brain(thinking) and ㅌeart (feelings) model is developed in Ry Nielsen and Ry (2004:97)

\section{References}

Carlson, Sune Executive Behaviour: A Study of the Work Load and the Working Methods of Managing Directors, Stockholm:Strömbergs

Gustavsen, Bjørn (1991) Strategier for utvikling i arbeidslivet Oslo: Tanum

Katzenbach, Jon R. and Douglas K. Smith (199) The Wisdom of Teams Boston: Harvard Business SchoolPress

Keller,Hanne Dauer, Søren Willert \& Nikolaj Stegeager(2011) Efteruddannelse som ledelsesudfordring - på sporet af en akademisk praksisuddannelse. In Helth, Poula (ed) Ledelse og læring i praksis, København:Samfundslitteraturpp231-271

Klausen,Kurt Klaudi (2001) Skulle det være noget særligt? København:Børsens Forlag Lindblom, Charles (1959) The Science of Muddling Through, Public Administrative Review vil XIX, Spring Lønstrup, Lars Topchefer kridter banen op som børn, DJøF-bladet Januar 2014

March, James (1995) Skraldespandsmodeller af beslutningstagen i organisationer i March, James (1995) Fornuft og forandring, København: Samfundslitteratur: pp 87-119 Mintzberg, Henry (1973) The Nature of Managerial Work, London: Prentice-Hall 
Nicolaisen,Line (ed ,2015) Fortællingen om en organisationsforandring.København: Pamphlet Pedersen, Dorthe and J.C. Ry Nielsen (2011) Deltagerorienteret lederuddannelse. In Helth, Poula(ed) Ledelse og læring i praksis. København: Samfundslitteratur, pp. 271-305 Quinn, James B. (1992) Strategies for Change: Logical Incrementalism. In Mintzberg, Henry \& James B. Quinn (ed) The Strategy Process, New Jersey: Prentice Hall: pp.96-105 Ry Nielsen,J.C. Hvad ledere gør - er ikke altid det rigtige eller godt nok, Officeren 1997 Ry Nielsen, J.C. (1998) Om brugen af billeder, en personlig beretning. In Klöcker-Larsen, Liza (ed) Bevisets stilling.København:Nyt fra Samfundsvidenskaberne: pp 77-88

Ry Nielsen, J. C. (2008) Deltagerorienteringen i undervisningen af MPA studerende. Refleksioner og praksis. Dansk Universitetspædagogisk Tidsskrift / vol.5, nr. 3, 2008:pp33-44

Ry Nielsen, J.C. The role of reflection in the pedagogical thinking and practice of the MPA programme at Copenhagen Business School, Teaching Public Administration, 2013, Vol.31(1), pp.55-68

Ry Nielsen .J.C and Morten Ry (2004)Tanker om organisationsændringer-brikker til mange ukendte puslespil. København: Nyt fra Samfundsvidenskaberne

Senge, Peter M. (1990) The Fifth Discipline, The Art and Practice of the Learning Organization, London: Century Business

www.cbs.dk

www.mpa.dk

www.mpg.dk

www.rh.dk

\footnotetext{
'Svend Engelund, Danish painter

ii See www.rh.dk

iii In all evaluations the MPA students agree that the cohesiveness is successfully achieved and also very important, see Pedersen and Ry Nielsen (2011)

iv See more on the student participation in the CBS programme in Ry Nielsen(2008)

${ }^{\mathrm{vi}}$ The Feet( action) Brain(thinking) and ㅌeart (feelings) model is developed in Ry Nielsen and Ry (2004:97)
} 